\title{
Environmental and Its Implications for Sustainable City: A Lesson From the Experience of Kampong Go Green in Malang
}

\author{
Erlita Cahyasari ${ }^{\text {a* }}$ \\ ${ }^{a}$ Universitas Brawijaya, Malang, East Java, Indonesia
}

\section{ARTICLE INFORMATION}

\section{Article history:}

Date Submission: 22 March 2021

First Revision: 26 March 2021

Accepted: 29 March 2021

Available Online: 13 April 2021

Keywords: community, sustainable city, governance, environment

\begin{abstract}
Sustainable city development is an attempt to increase society's life quality. Environmental awareness is no longer local normativity, but a construct of shared life. A good environmental awareness is not merely a national discourse but has become a global and urgent importance. This paper aims to identify and analyze the implications of environmental governance in sustainable city development. It is a descriptive research with qualitative approach. The result of this study shows that the community and the authorities in kampong Kampong Go Green of Malang are the main factors that determine the success of environmental governance process in sustainable city development.
\end{abstract}

\section{INTISARI}

Pembangunan kota yang berkelanjutan merupakan upaya untuk meningkatkan kualitas hidup masyarakat. Kesadaran lingkungan bukan lagi normativitas lokal, tetapi konstruksi hidup bersama. Kesadaran lingkungan yang baik bukan hanya wacana nasional tetapi telah menjadi kepentingan global dan mendesak. Tulisan ini bertujuan untuk mengidentifikasi dan menganalisis implikasi tata kelola lingkungan dalam pembangunan kota berkelanjutan. Merupakan penelitian deskriptif dengan pendekatan kualitatif. Hasil penelitian ini menunjukkan bahwa masyarakat dan pihak berwenang di kampung Kampong Go Green Kota Malang merupakan faktor utama yang menentukan keberhasilan proses tata kelola lingkungan dalam pembangunan kota berkelanjutan.

2021 FIA UB. All rights reserved.

\section{Introduction}

An environmentally sound sustainable development is an integrity combination between human system and ecosystem as their interaction. According to Girardet (2004), “A 'sustainable city' enables all its citizens to meet their own needs and to enhance their well-being without damaging the natural world or endangering the living conditions of other people, now or in the future."
The objectives of developing sustainable city are (a) to find strategies for reducing the use of natural resources; (b) to rationalize and manage material flows in urban areas efficiently and effectively; (c) to protect and improve the health of urban residents; (d) to maintain equitable convenience in access to resources and services; and (e) to increase cultural and social diversity. The establishment of governance which is based on the principal of environmental governance means that the management of government affairs in the environment

* Corresponding author. Tel.: +62-821-396-1616-00; e-mail: erlita@ub.ac.id 
and natural resources sectors is optimally carried out and is in accordance with the protection and preservation of natural environment to support sustainable city development.

City government needs the participation of the whole citizens in its effort to generate policies to obtain sustainable conditions. In relation to this, UN Habitat (2007) stated that city development aims at realizing a compact city, preserving open green areas, reducing the use of motor vehicles, reducing waste and pollution, reusing and recycling materials, creating a communityoriented environment, allocating decent and affordable public housing, increasing social equality, and developing restorative local economy.

As one of the biggest cities in East Java, Malang can be categorized into a metropolitan city. In recent years, Malang is directed to develop a sustainable city, focusing on environmental, economical and social sustainability. This is in accordance with the development mission for 2013-2018 of Malang government, some of which are increasing the development of infrastructures and the supporting capacity of the integrated and sustainable city, creating an orderly spatial management, and developing an environmentally sound city. Besides the above mission, there is an ongoing agenda implemented by Malang government that is intended to overcome problems related to: (a) poverty; (b) famine; (c) health; (d) gender equality; (e) clean water and sanitation; (f) clean and affordable energy; (g) employment and economic growth; (h) social gaps; (i) city and community; (j) responsible consumption and production; (k) acts on climate change; (1) under water life; (m) life on land; (n) peace and justice; and (o) global cooperation.

There is one specific area in Malang that has succesfully put the above agenda into practice. The area is called Glintung Go Green (Kampong Go Green) kampong. Residents of this kampong are doing an activity which is called 'water banking movement' (GEMAR). It was initiated with a simple planting movement in the neighbourhood, launched in February 2012. This movement was also supportive towards the local government's planting program called "Malang Ijo Royo-Royo" (Malang Go Green). This movement has generated positive impacts on the kampong, some of which are: (a) the regular flooded areas have become high level ground water infiltration areas (water surface in infiltration wells rises to 2 meters in 2 years); (b) the temperature has dropped 2 degrees compared to surrounding areas; (c) they yield compost up to $13 \mathrm{~kg}$; and (d) they present green business opportunities. The participation of society in an effort to establish and develop a sustainable city is highly fundamental. Development within the framework of city development is essentially a process of efforts carried out by the government and the citizens to reach the improvement of life's quality while taking the conditions of the environment into accounts. Hence, the purpose of this writing is to identify and analyze the implications of the environmentally sound governance towards the sustainability of city development.

\section{Research Methods}

This writing is a descriptive research with qualitative approach that enables the researcher to describe the phenomena and analyze the relations that emerge among them. The result of this study is described in a narrative by means of interviews, observations, and documentation of instruments. The use of these instruments is meant to get clear descriptions related to information on environmental governance in sustainable city development. The data obtained through this research is empirical (observed) and is valid. A valid data is definitely reliable and objective. Since every research has its own use and purpose, this one emphasizes on analyzing and describing the object's condition in a detailed, clear, thorough, and accurate ways.

\section{Result and Discussion}

Neighbourhood planting movement was a simple activity to mark the Kampong Go Green movement commenced in 2012. This was also intended to support the program of Malang government in realizing planting movement in Malang called "Malang Ijo Royo-Royo" (Malang Go Green). In practice, people agreed on the obligation of planting greeneries in their homes as a requirement to get residential administration services. The head of the neighbourhood (RW) would help provide a plant for those who could not afford one, with the obligation to take care of the plant. With the running of time, the Kampong Go Green movement has been continuously developed and has become trending topic for daily discussions among the community and within neighbourhood meetings. As a result, the plants planted today are not only green and pretty but also edible.

People in the kampong have independently learnt how to plant vegetables and crops. With the help and direction from East Java Agricultural Technology Study Center (Balai Pengkajian Teknologi Pertanian Jawa Timur), they apply a varied planting technology, starting from a conventional way of planting, which is done on a piece of land or in pots/ polybags, to hydroponic system. These systems are introduced so that the people can choose one which is most suitable for their condition. The work of the community in applying Kampong Go Green movement in Glintung caught the attention of Malang Government. This was mainly because the movement was initiated and financed by the community themselves. In 2013, Glintung participated in Kampung Bersinar competition, a green Decofresh kampong movement, and 
in 2014 it was one of the top five the cleanest kampong in Malang.

Not only did The Glintung Go Green movement tackle the environment sustainability issue, but it also resolved the main issue on the settlement's infrastructure, especially on water channel management. Flood had been a regular problem in rainy seasons in this kampong. The reason was the area inhabited by 303 homes did not have good infrastructure. The neighbourhood was dirty and was prone to diseases. The high level of density and the lack of drainage caused a bigger issue when the rainy season came. Water could not flow easily. People started to think of ways to prevent the risk of a more severe flood. Then they came up with GEMAR (Gerakan Menabung Air) or Water Banking Movement. Traditionally, people built canals to prevent flood. In GEMAR, they build infiltration wells instead. The concept is basically directing the water that flows in the sewage towards the injection wells to save water. This system increases water reservoir and decreases micro temperature. Also contributing to the water banking movement are the bio pores and infiltration gutters. At the moment Glintung has already got 675 bio pores and 7 infiltration wells. Now GEMAR has become one of the solutions for flood in the area. Furthermore, it is expected that GEMAR create a healthy, ecofriendly, and flood-free environment. To date, this movement has given a number of advantages to the community, they are: (a) minimizing flooding risk in Glintung area so that people can actually anticipate the overflow of water; (b) increasing the water level in infiltration wells so that they can use the water to support urban farming activity; and (c) making GEMAR as an alternative to renewable source of energy in the coming future.

Success that has been achieved by kampong Kampong Go Green as a good water conservation, urban farming, and waste management area has made this kampong an educational travelling destination. The number of tourists is increasing each day and indirectly elevates community's income and accelerates velocity of money through the development of small and medium enterprises (UMKM) managed by Kampong Go Green Cooperation. GEMAR in Kampong Go Green kampong has positively impacted the framework of sustainability development goals (SDG's). It may also become the answer to any crises in the future, which include food, water, and energy.

The purposes of developing sustainable city are reducing the use of space and natural resources, rationalizing and efficiently managing material flows in urban areas, protecting and improving urban society's health, maintaining equitable ease in accesses to resources and services, and increasing cultural and social diversity (EEA, 2011). In practice, however, the increase in urban development generates problems for the environment. More developments equal to more irresponsible use of natural resources that disregards environmental sustainability. As stated by Feris (2010), "developments have significant impacts on the environment, either positive or negative".

Decision making stage in the sustainable city development program is not a process that just happens. It must be based on a number of considerations, which is adjusted to society's needs and interests that has been previously scaled based on priority. In relation to realizing sustainable city, society's involvement in making decision cannot be neglected. Society is the actor and at the same time the target in the participatory development programs. This will build responsibility within society because they are involved in determining the course, the means, the objectives, and the targets of the program. According to Todaro (2000), "development basically emphasizes on humanity aspects such as supporting the continuity of life or human's ability to provide their own needs". In addition to this, Pozdniakova (2017) says that human beings are the main factor, whether as subjects or objects, because they are the main ecological factor.

The development carried out by the government is of course aimed at realizing a prosperous society. Hence, society has an important position in the development process executed by the government. It is impossible to reach the goals of development if the society is always left behind. Therefore, society's participation greatly influences the success of development process itself. As stated by Azizy (2007), one of the values of good government principles is its commitment to protecting living environment. This principle stresses on the balance between the utilization of natural resources and their protection or conservation, the enforcement of sustainable development principle, and the low level of environmental destruction.

The implementation of Kampong Kampong Go Green program is differentiated within several activities, they are: plants procurement, plants treatment, environment waste-free activity, injection wells and constructions of bio pores, educational tours, and empowerment activities engineered by Kampong Go Green cooperation such as making therapy enzyme, therapy drinks, recycled crafts, and GEMAR workshop. Glintung Go Green is an innovation program created by an urban kampong that involves the community in relation to environmental conservation and flood prevention. This program is intended to increase community's welfare through the improvement of life quality and community's environment and to promote local government's living environment management by stressing on the involvement of community. This is an example of how both community and the local government are involved in the process of kampong 
Kampong Go Green environment management and how both benefit from it. This is to say that the program has generated material, social, and individual benefits shared by the community and the government. The material benefits are related to the increase of income, assets, etc. The social benefits are linked with the education, health, and other services. Hence, the individual benefits are closely connected to self development and public trust. We cannot deny that in this modern era not all development aspects are eco friendly. Thus, to reduce the risks on the environment, environmental governance is crucial. This concept is expected to make the environment as the underline for urban development. Harpham \& A. Boateng (1997) define environmental management as "a set of values and norms that govern the relationship between the state and its people in the use, control, and management of living environment". Environmental management provides a concept where the public and private sectors are equally involved in supporting the regulations with environmental orientation. This can be observed through this diagram:

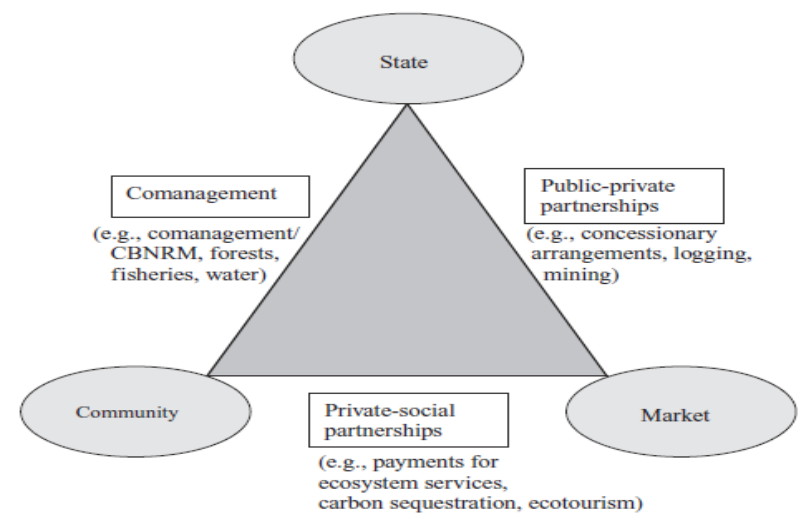

Figure 1 Mechanisms and strategies of environmental governance. Abbreviation: CBNRM, community-based natural resource management

Source: Lemos \& Arun, 2006

The establishment of governance is considered as democratic in terms of its process if the related government is able to provide space for the involvement of the society in making or in criticizing the implemented local policies. The establishment of governance is considered as substantially democratic if local policies composed by the government can reflect people's aspirations. Every development in one area is regarded as successful if it benefits the society. Hence, society is given opportunities to judge the attained results. People's participation in expressing their judgments on development is a positive support for the government. Control on development can be done by formulating the norms, standards and regulations, and regular observation on the execution of the regulations. Parallel to this, control on Kampong Go Green implementation is technically done by the community by doing plants preservation and environment cleaning. Control and evaluation systems are carried out by the internal Kampong Go Green members, which consist of Kampong Go Green cooperation, RW, RT, and Suku Dalu group. The number of people who actively participate in this Kampong Go Green activity is by far only $2 \%$ of the total number of the community, or only around 16 people. It proves that they need to construct a better institution and system that enable all layers of community to be equally responsible and enjoy the economy benefits from the establishment of Kampong Go Green. In addition to this, there are several things that can be done to successfully implement environmental governance concept, such as (a) strengthening local community and increasing their understanding on the matter; (b) increasing the participations from local community's and local non-governmental organizations in the formulation, implementation, and observation of environment program policies; (c) empowering the community through education, political participation, and health and nutrition improvements; and (d) increasing the collaborations between public and private sectors in planning green market.

\section{Conclusion}

Environmental governance has become an important part to realize sustainable city development. Environment management must be conducted by both the government and the society to formulate policies related to the establishment of a good and healthy environment. It is found that:

a) The existence of kampong Kampong Go Green community is very effective in controlling the existing environmental management; and

b) Community groups which have been formed are used as a medium to express community's ideas and suggestions. Some of the community groups are Suku Dalu, waste bank, and Kampong Go Green cooperation.

The community in kampong Kampong Go Green takes care and nurtures the plants, keeps their environment clean, and continuously conducts gotong royong and kerja bakti (volunteer neighbourhood works) in a regular basis.

\section{References}

Azizy, Qodry. (2007). Change Management dalam Reformasi Birokrasi. Jakarta: PT. Gramedia Pustaka Utama.

European Environment Agency (EEA). (2011). Urban Atlas. Copenhagen: EEA.

Feris, L.A. (2010). The Role of Good Environmental Governance In The Sustainable Development of South Africa. Potchefstroom Electronic Law 
Journal/ Potchefstroomse Elektroniese Regsblad, (13)1, 73-99. DOI: 10.4314/pelj.v13i1.55354

Girardet, Herbert. (2000). Urban Sustainability: Cities, People, Planet. Liverpool (UK): Schumacher Lectures.

Lemos, Maria Carmen., \& Agrawal, Arun. (2006). Environmental Governance. Annu. Rev. Environ. Resour, 31, 297-325. DOI: 10.1146/annurev.energy.31.042605.135621

Harpham, Trudy., \& Kwasi A. Boateng. (1997). Urban governance in relation to the operation of urban services in developing countries. Habitat International, 21(1), 65-77.

Pozdniakova, Anna M. (2017). Smart Sustainable Cities: The Concept And Approaches To Measurement. Acta Innovations, Issue 22, 5-19.

Todaro, Michael P. (2000). Pembangunan Ekonomi di Dunia Ketiga. Jakarta: Penerbit Erlangga.

UN Habitat. (2007). Inclusive and Sustainable Urban Planning: A Guide for Municipalities: Vol. I: An Introduction to Urban Strategic Planning. Kenya: UB Habitat. 